\title{
UNEXPECTED INHIBITORY CASCADE IN THE MOLARIFORMS OF SLOTHS (FOLIVORA, XENARTHRA): A CASE STUDY IN XENARTHRANS HONOURING GERHARD STORCH'S OPEN-MINDEDNESS
}

\author{
LUCIANO VARELA ${ }^{1,2}$, P. SEBASTIÁN TAMBUSSO ${ }^{1,2}$, RICHARD A. FARIÑA $^{1,2, *}$ \\ Departamento de Paleontología, Facultad de Ciencias, Universidad de la República, Iguá 4225, 11400 Montevideo, Uruguay; e-mail: \\ luciano.Ivr@gmail.com.uy,stambusso@fcien.edu.uy,dogor@netgate.net.uy. \\ 2 Servicio Académico Universitario y Centro de Estudio Paleontológicos (SAUCE-P), Universidad de la República, Santa Isabel s/n, 91500 \\ Sauce, Departamento de Canelones, Uruguay. \\ * corresponding author
}

Varela, L., Tambusso, P. S., Fariña, R. A. (2020): Unexpected inhibitory cascade in the molariforms of sloths (Folivora, Xenarthra): a case study in xenarthrans honouring Gerhard Storch's open-mindedness. - Fossil Imprint, 76(1): 1-16, Praha. ISSN 2533-4050 (print), ISSN 2533-4069 (online).

\begin{abstract}
The inhibitory cascade (IC) represents a developmental model that explains the evolution of molar relative sizes, originally described in rodents but later validated in several mammalian groups. The IC comprises signalling molecules produced by the first molar buds that inhibit the development of subsequent molars and molecules from surrounding tissues that have opposite effects. Sloths, as xenarthrans, present many peculiarities in their dentition, like tooth and enamel loss, homodonty, and changes in the typically mammalian dental formula. Here, we test the existence of an IC and explore the evolution of the lower dentition in sloths. We studied the variability of molariform proportions in 20 specimens of the Late Pleistocene ground sloth Lestodon armatus. We also analysed molariforms proportions in 53 sloth genera to explore evolutionary trends. Our results show that the lower dentition of most sloths complies with the IC model, despite the difficulties of assessing dental homologies with other mammals. Furthermore, we tested the existence of different patterns among families, obtaining support for models taking mylodontids and orophodontids separately from the rest of sloths. Also, members of Mylodontidae show a unique IC pattern, with a slope considerably higher than 2 and an $\mathrm{mf} 1 \leq \mathrm{mf} 2<<\mathrm{mf} 3$ configuration. This pattern could be related to the morphological adaptations to grazing showed by mylodontids during most of their evolutionary history.
\end{abstract}

Key words: sloths, inhibitory cascade, macroevolution, tooth evolution, molariforms

Received: April 2, 2019| Accepted: February 7, 2020 | Issued: November 9, 2020

\section{Introduction}

One of us (RAF) had the pleasure to meet Gerhard Storch in connection with the preparation of the proceedings of the Xenarthra meeting held in Jena in 2001, published as a special issue of Senckenbergiana biologica (Fariña et al. 2003). Here we intend to honour his wide legacy that dealt with taxonomy, palaeobiology, biochronology, and palaeobiogeography of mainly small mammals in which he made relevant contributions (Franzen et al. 2018). Among the several Palaeogene taxa Storch described, an astonishing finding of a complete skeleton of a clearly anteating mammal in Eocene sediments from a pit not far from the city of Frankfurt am Main, led Storch (1981) to create the genus Eurotamandua. Originally, as the name implies, considered as the first myrmecophagid (Xenarthra) outside of South America, it was later classified as a basal member of Afrotheria (see Hunter and Janis 2006), and finally as a pholidotan without scales (Gaudin et al. 2009).

Xenarthrans are a group of mammals that include small to medium size armadillos, anteaters, and tree sloths as living species. However, their diversity in the fossil record is astonishing, including many glyptodonts and ground sloths (some of gigantic size; see Fariña et al. 1998, Christiansen and Fariña 2003) as completely extinct forms. Xenarthrans originated in South America during the early Cenozoic and, following a long-term diversification in that subcontinent, they spread into Central and North America following the Great American Biotic Interchange (Fariña et al. 2013). Prior to the extinctions near the Pleistocene-Holocene limit, the group reached great taxonomic and morphological diversity (Varela et al. 2018). Folivora (see Fariña and Vizcaíno 2003), the group that includes both living and extinct sloths, is currently represented by only two genera, the obligatory 
arboreal sloths Bradypus and Choloepus. However, as mentioned before, the fossil history of this clade was much more diverse along the Cenozoic, including about 90 genera (McKenna and Bell 1997), a number continuously growing with new findings in less-explored parts of the Americas (e.g., Pujos et al. 2012).

Xenarthrans differ from the rest of the mammalian clades by the individual morphology and number of teeth (McDonald 2003). When present, teeth in most adult xenarthrans lack enamel and are usually homodont, hypselodont, tubular, and primarily composed of orthodentine and vasodentine, which makes it difficult to identify homologies with the teeth and cusps of other mammals (Vizcaíno 2009, Hautier et al. 2016). In sloths, the dentition is reduced to a maximum of five upper and four lower teeth, with caniniforms (cf) present in megalonychids and some nothrotheriids, megatheriids, and mylodontids (Vizcaíno 2009). Hautier et al. (2016) studied the prenatal dental ontogeny of extant sloths, showing that the upper caniniforms are not homologous in both genera and their lower caniniforms are not homologous to the lower canines of other mammals. Furthermore, based on the timing of mineralizations of each tooth, they showed that the lower molariforms (mf) of both sloths are probably homologous to the $\mathrm{dp} 3, \mathrm{dp} 4$, and $\mathrm{m} 1$ of the rest of mammals. These results depict the complex evolution of the dentition in these two distantly related sloths (Gaudin 2004, Varela et al. 2018, Delsuc et al. 2019, Presslee et al. 2019) as well as in Folivora in general, which highlights the difficulties of defining dental homologies in extant and extinct sloths.

The evolutionary developmental (evo-devo) field consists of the integration of evolutionary, adaptational, and developmental approaches to explore the mechanistic relationships between the processes of individual development and phenotypic change during evolution (Müller 2007). The mammalian dentition represents a great system for the study of macroevolutionary patterns and the link between phenotypic variation, development, and evolutionary processes in deep time, allowing the inclusion of fossil taxa many times largely known by their tooth remains. Some years ago, Kavanagh et al. (2007) established a developmental model that can explain the evolution of the relative sizes of lower molars in murine rodents. The inhibitory cascade model (IC model) showed that signalling molecules produced by the developing first molar buds inhibited the development of subsequent molars, while molecules from the surrounding tissues had the opposite effect. Consequently, this balance between inhibition and activation during molar development results in a predictable relationship between molar sizes, with phenotypes (and their change across taxa and time) constrained to fall within expected patterns, namely $\mathrm{m} 1>\mathrm{m} 2>\mathrm{m} 3, \mathrm{~m} 1 \approx \mathrm{m} 2 \approx \mathrm{m} 3$, or $\mathrm{m} 1<\mathrm{m} 2<\mathrm{m} 3$. The IC model has been studied in several extant (Kavanagh et al. 2007, Polly 2007, Labonne et al. 2012, Asahara 2013, Bernal et al. 2013) and extinct (Wilson et al. 2012, Schroer and Wood 2015, Asahara et al. 2016, Evans et al. 2016, Gomes Rodrigues et al. 2017) mammals, with evidence supporting its existence deep in mammalian evolution (Halliday and Goswami 2013). Although it applies to many clades, it cannot be generalized across all mammals, and some examples of mammalian groups that fall outside the model prediction also exist (Polly 2007).
Moreover, different patterns in different mammalian groups were found, supporting the existence of different intensities in inhibition and activation across the cascade, and allowing the evolution of different morphotypes not strictly predicted by the model (Asahara 2013). Interestingly, in many reported cases, this variability associated with the inhibitory cascade is related to different adaptations to certain diets. For example, in murine rodents, faunivorous species show larger $\mathrm{m} 1$ (and loss of $\mathrm{m} 3$ ), whereas herbivorous species have approximately equal-sized molars (Kavanagh et al. 2007). In canids, carnivorous species exhibited the pattern $\mathrm{m} 1>>\mathrm{m} 2>\mathrm{m} 3$, omnivorous species exhibited $\mathrm{m} 1>\mathrm{m} 2$ $>\mathrm{m} 3$ and insectivorous species have equal-sized molars (Asahara 2013). Finally, Evans et al. (2016) reported that an inhibitory cascade pattern was present along the dp3, dp4, and $\mathrm{m} 1$ in hominins, integrating to the already proposed cascade through $\mathrm{m} 1, \mathrm{~m} 2$, and $\mathrm{m} 3$ and supporting the existence of a developmental control across the five teeth (the idea of a consistent pattern across the primary dentition was originally proposed by Butler 1939, but the exact mechanism was unknown at the time).

In this study, considering the dental homologies of sloths (Hautier et al. 2016) and the existence of an inhibitory cascade in dp3, dp4, and $\mathrm{m} 1$ in hominins (Evans et al. 2016), we explore the evolution of the lower dentition in sloths aiming at testing the existence of the inhibitory cascade in their molariforms. We also discuss the significance of the observed patterns across sloth families and their potential relationship with diet adaptations.

\section{Materials and methods}

\section{Taxon sampling and data acquisition}

In order to study the existence of the inhibitory cascade in the lower dentition of sloths, we focused on the dental dimensions of the last three molariforms. These last teeth are commonly named $\mathrm{mf} 1, \mathrm{mf} 2$, and $\mathrm{mf} 3$ and are morphologically different from the first lower tooth, which has a caniniform morphology in most sloths and is referred as cf1. However, some sloths, like the Megatheriinae, present a first tooth with molariform morphology and thus have a lower dental formula composed of $\mathrm{mf1}, \mathrm{mf}$, $\mathrm{mf} 3$, and $\mathrm{mf} 4$. In those cases, we considered the last three molariforms as homologous with the last three molariforms of the rest of sloths (as tentatively proposed by Hautier et al. 2016) and the first molariform as homologous with the caniniform, with $\mathrm{mf} 2, \mathrm{mf} 3$, and $\mathrm{mf} 4$ considered as $\mathrm{mf} 1$, $\mathrm{mf} 2$, and $\mathrm{mf} 3$ in those taxa (Text-fig. 1). We collected data from juvenile and adult specimens of Lestodon armatus, a fossil ground sloth belonging to the family Mylodontidae, deposited in the collections of Museo Nacional de Historia Natural, Montevideo, Uruguay (MNHN); Museo Municipal "Bautista Rebuffo", Colonia, Uruguay (MMBR); Museo Paleontológico "Armando Calcaterra", Colonia, Uruguay (MPAC); Colección Arroyo del Vizcaíno, Sauce, Uruguay (CAV); Museo Argentino de Ciencias Naturales "Bernardino Rivadavia", Buenos Aires, Argentina (MACN); Museo de La Plata, La Plata, Argentina (MLP), in order to explore the molariforms variability among a single species (Tab. 1). The 
a

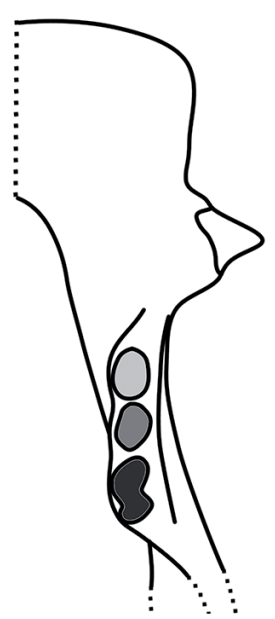

b

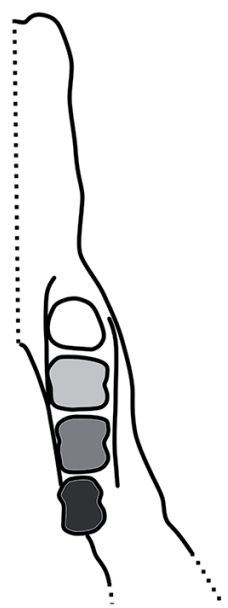

C

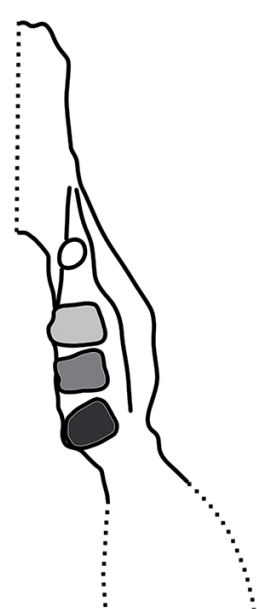

d

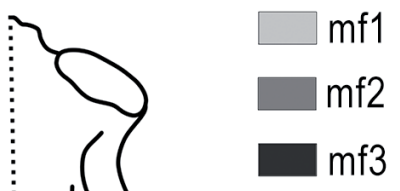

Text-fig. 1. Examples of lower dentition and molariforms homologies in the four families of extinct sloths. a: Mylodontidae, b: Megatheriidae, c: Nothrotheriidae, d: Megalonychidae.

largest mylodontid Lestodon armatus was selected because it is probably the most abundant ground sloth found in Pleistocene deposits of Uruguay (Fariña et al. 2014, Varela and Fariña 2016), along with the large number of remains found in Argentina and Brazil, and because, despite this, it remains relatively little studied. We also collected data from sloth genera covering all sloth families from a revision of the literature, as well as published images and measurements of

Table 1. Molariforms area measurements and proportions in studied specimens of Lestodon armatus. Measurements in $\mathbf{~ m m}^{2}$. $\% \mathrm{mf}$ : percentage of area occupied by $\mathrm{mf} 2$ in relation to the total area occupied by the last three teeth.

\begin{tabular}{|l|c|c|c|c|c|c|}
\hline Specimen & mf1 & mf2 & mf3 & $\begin{array}{c}\text { mf2/ } \\
\text { mf1 }\end{array}$ & $\begin{array}{c}\mathbf{m f 3 /} \\
\mathbf{m f 1}\end{array}$ & \% mf2 \\
\hline CAV 125 & 543.0 & 563.2 & 720.0 & 1.04 & 1.33 & 30.8 \\
\hline CAV 391 & 364.9 & 419.3 & 639.5 & 1.15 & 1.75 & 29.5 \\
\hline CAV 595 & 404.2 & 458.5 & 650.0 & 1.13 & 1.61 & 30.3 \\
\hline CAV 648 & 501.4 & 536.8 & 685.4 & 1.07 & 1.37 & 31.1 \\
\hline CAV 847 & 405.1 & 436.0 & 543.2 & 1.08 & 1.34 & 31.5 \\
\hline CAV 897 & 486.8 & 488.4 & 687.5 & 1.00 & 1.41 & 29.4 \\
\hline CAV 898 & 122.6 & 155.7 & 212.0 & 1.27 & 1.73 & 31.8 \\
\hline CAV 1261 & 381.2 & 401.1 & 499.9 & 1.05 & 1.31 & 31.3 \\
\hline CAV 1571 & 406.4 & 405.0 & 484.2 & 1.00 & 1.19 & 31.3 \\
\hline CAV 1572 & 327.7 & 344.5 & 438.5 & 1.05 & 1.34 & 31.0 \\
\hline MACN 9470 & 467.8 & 496.8 & 722.9 & 1.06 & 1.55 & 29.4 \\
\hline MACN 10830 & 471.6 & 582.7 & 867.7 & 1.24 & 1.84 & 30.3 \\
\hline MLP 3-29 & 529.4 & 619.1 & 806.8 & 1.17 & 1.52 & 31.7 \\
\hline MLP 3-30 & 342.4 & 385.8 & 607.5 & 1.13 & 1.77 & 28.9 \\
\hline MMBR 1110 & 68.5 & 68.5 & 92.9 & 1.00 & 1.36 & 29.8 \\
\hline MMBR sn-5 & 295.5 & 339.6 & 503.1 & 1.15 & 1.70 & 29.8 \\
\hline MNHN 2776 & 388.7 & 396.8 & 515.0 & 1.02 & 1.32 & 30.5 \\
\hline MNHN 2784 & 327.7 & 360.0 & 549.0 & 1.10 & 1.68 & 29.1 \\
\hline MNHN 2785 & 429.1 & 447.3 & 614.1 & 1.04 & 1.43 & 30.0 \\
\hline MNHN 2786 & 472.2 & 488.6 & 690.8 & 1.03 & 1.46 & 29.6 \\
\hline
\end{tabular}

museum specimens (Tab. 2) to evaluate the IC model in this clade. In this case, a single adult individual was measured, which (although not ideal, is common in macroevolutionary analyses covering fossil species due to the limited sample or fragmentary nature of many specimens) could produce some artefacts in the analysis and should be considered when discussing the results. A total of 20 specimens of L. armatus were included in the first analysis, while a total of 53 sloth genera were included in the second approach.

Tooth area is commonly measured by the product of the tooth length and width in most mammalian groups. However, in the case of sloths, especially mylodontids, the teeth are circular, elliptical, and/or lobated in section (Textfig. 1). Therefore, we measured occlusal tooth area using ImageJ (Rueden and Eliceiri 2019) in images of the lower molariform row from published literature and collection specimens (Tabs 1, 2). A similar approach was previously used by Vizcaíno et al. (2006) in sloths for the study of the dental occlusal surface area and its relation with body mass and food habits.

\section{The inhibitory cascade model}

The IC model, originally proposed by Kavanagh et al. (2007), assumes a linear effect of the activator and inhibitor ratio on tooth proportions. Relative molar size and position follows the equation $y=1+[(a-i) / i](x-1)$ where $y$ is the relative molar size estimated from occlusal area, $x$ is the position of the molar in the tooth row, $a$ is the strength of activation, and $i$ is the strength of inhibition. This equation predicts that $\mathrm{M} 1=1, \mathrm{M} 2=a / i$ and $\mathrm{M} 3=2 a / i-1$.

The majority of the published research on the IC model used the RMA model in order to fit regressions. However, there is a current discussion regarding the use of OLS and RMA regressions and their impact on parameter estimations (Smith 2009). Considering this, and in order to compare our results with published analyses, we used both OLS and RMA to fit regressions to the Lestodon data. Furthermore, the lack of independency in biological data due to the existence of phylogenetic relationships between species has been 
Table 2. Molariforms area measurements and proportions in studied sloth genera. Measurements in $\mathrm{mm}^{2}$. cf: caniniform, mf: molariform, $\% \mathrm{mf} 2$ : percentage of area occupied by $\mathrm{mf} 2$ in relation to the total area occupied by the last three teeth.

\begin{tabular}{|c|c|c|c|c|c|c|c|c|}
\hline Genus & cf1 & mf1 & $\mathrm{mf} 2$ & $\mathrm{mf3}$ & $\mathrm{mf} 2 / \mathrm{mf} 1$ & $\mathrm{mf} 3 / \mathrm{mf} 1$ & $\%$ mf2 & Reference \\
\hline Octodontotherium & 106.9 & 141.8 & 308.1 & 257.5 & 2.17 & 1.82 & 43.6 & Hoffstetter 1954 \\
\hline Octomylodon & - & 665.2 & 745.4 & 761.0 & 1.12 & 1.14 & 34.3 & Scillato-Yané 1977 \\
\hline Pseudoprepotherium & 215.8 & 191.4 & 210.8 & 349.2 & 1.10 & 1.82 & 28.1 & Hirschfeld 1985 \\
\hline Thinobadistes & 333.7 & 150.5 & 227.2 & 489.7 & 1.51 & 3.25 & 26.2 & Webb 1989 \\
\hline Lestodon & 505.5 & 394.6 & 427.1 & 587.4 & 1.09 & 1.50 & 30.3 & This work \\
\hline Pleurolestodon & 453.0 & 328.0 & 340.4 & 660.5 & 1.04 & 2.01 & 25.6 & $\begin{array}{l}\text { Rovereto 1914, Saint-André et } \\
\text { al. } 2010\end{array}$ \\
\hline Glossotherium & 374.6 & 424.2 & 567.7 & 1097.7 & 1.34 & 2.59 & 27.2 & Mcafee 2009 \\
\hline Paramylodon & 242.8 & 380.5 & 411.6 & 792.9 & 1.08 & 2.08 & 26.0 & Mcafee 2009 \\
\hline Nematherium & 35.5 & 44.8 & 51.6 & 79.0 & 1.15 & 1.76 & 29.4 & Scott 1904 \\
\hline Catonyx & 337.0 & 233.1 & 231.9 & 342.4 & 0.99 & 1.47 & 28.7 & Cartelle et al. 2009 \\
\hline Scelidotherium & 196.9 & 182.8 & 186.9 & 304.6 & 1.02 & 1.67 & 27.7 & Bargo 2001a \\
\hline Mylodon & 222.7 & 316.2 & 354.3 & 462.8 & 1.12 & 1.46 & 31.3 & Bargo 2001a \\
\hline Acratocnus & 61.2 & 50.0 & 56.3 & 59.7 & 1.13 & 1.20 & 33.9 & Matthew and Paula Couto 1959 \\
\hline Neocnus & 10.3 & 20.4 & 21.4 & 25.2 & 1.05 & 1.23 & 32.0 & Matthew and Paula Couto 1959 \\
\hline Parocnus & 24.8 & 57.5 & 69.3 & 89.3 & 1.21 & 1.55 & 32.1 & Matthew and Paula Couto 1959 \\
\hline Megalocnus & 150.3 & 291.2 & 342.9 & 404.0 & 1.18 & 1.39 & 33.0 & Matthew and Paula Couto 1959 \\
\hline Pliometanastes & 102.4 & 245.5 & 261.0 & 271.2 & 1.06 & 1.10 & 33.6 & Hirschfeld 1981 \\
\hline Megalonyx & 350.1 & 259.1 & 273.8 & 278.3 & 1.06 & 1.07 & 33.8 & Savage 1946 \\
\hline Pronothrotherium & 22.1 & 80.0 & 93.0 & 91.7 & 1.16 & 1.15 & 35.1 & Rovereto 1914 \\
\hline Mionothropus & 37.9 & 115.5 & 97.6 & 102.7 & 0.85 & 0.89 & 30.9 & De Iuliis et al. 2011 \\
\hline Nothrotherium & - & 84.8 & 95.2 & 98.0 & 1.12 & 1.16 & 34.2 & Quiñones et al. 2017 \\
\hline Nothrotheriops & - & 186.2 & 216.6 & 221.8 & 1.16 & 1.19 & 34.7 & Quiñones et al. 2017 \\
\hline Eucholoeops & 62.1 & 75.7 & 79.8 & 86.9 & 1.05 & 1.15 & 32.9 & De Iuliis et al. 2014 \\
\hline Hapalops & 33.7 & 48.8 & 54.6 & 60.5 & 1.12 & 1.24 & 33.3 & Scott 1903 \\
\hline Eremotherium & 2013.5 & 2686.3 & 2275.5 & 1770.8 & 0.85 & 0.66 & 33.8 & McDonald and Lundelius 2009 \\
\hline Megatherium & 1902.7 & 2396.8 & 2155.5 & 1442.2 & 0.90 & 0.60 & 36.0 & Bargo 2001a \\
\hline Schismotherium & 20.8 & 36.4 & 46.4 & 54.3 & 1.27 & 1.49 & 33.8 & Scott 1904 \\
\hline Pelecyodon & 8.5 & 32.8 & 42.2 & 44.1 & 1.29 & 1.34 & 35.5 & Scott 1904 \\
\hline Ahytherium & 88.0 & 321.9 & 329.1 & 360.4 & 1.02 & 1.12 & 32.5 & Cartelle et al. 2008 \\
\hline Proscelidodon & 103.3 & 98.0 & 108.1 & 138.5 & 1.10 & 1.41 & 31.4 & Taglioretti et al. 2014 \\
\hline Prepoplanops & 47.2 & 119.9 & 123.9 & 146.0 & 1.03 & 1.22 & 31.8 & Carlini et al. 2013 \\
\hline Anisodontherium & 684.1 & 695.7 & 560.9 & 418.6 & 0.81 & 0.60 & 33.5 & Brandoni et al. 2011 \\
\hline Urumacotherium & 186.9 & 140.8 & 125.3 & 117.1 & 0.89 & 0.83 & 32.7 & Negri and Ferigolo 2004 \\
\hline Simomylodon & 138.6 & 99.0 & 106.0 & 193.5 & 1.07 & 1.95 & 26.6 & Saint-André et al. 2010 \\
\hline Octodontobradys & 223.1 & 271.6 & 349.3 & 330.9 & 1.29 & 1.22 & 36.7 & Dos Santos et al. 1993 \\
\hline Brievabradys & 42.8 & 19.7 & 21.2 & 28.7 & 1.07 & 1.46 & 30.4 & Villarroel 2000 \\
\hline Lestobradys & 310.0 & 231.3 & 268.5 & 448.4 & 1.16 & 1.94 & 28.3 & Rinderknetcht et al. 2010 \\
\hline Valgipes & 139.5 & 124.2 & 122.0 & 136.7 & 0.98 & 1.10 & 31.9 & Cartelle et al. 2009 \\
\hline Bolivartherium & 305.3 & 243.9 & 326.0 & 507.0 & 1.34 & 2.08 & 30.3 & Carlini et al. 2006 \\
\hline Thalassocnus & - & 146.9 & 161.7 & 183.7 & 1.10 & 1.25 & 32.9 & $\begin{array}{l}\text { Mcdonald and Muizon 2002, } \\
\text { Muizon et al. } 2003\end{array}$ \\
\hline Pyramiodontherium & 1325.5 & 1678.4 & 1470.4 & 903.4 & 0.88 & 0.54 & 36.3 & Carlini et al. 2002 \\
\hline Pseudortotherium & 24.0 & 72.2 & 67.7 & 65.7 & 0.94 & 0.91 & 32.9 & Scillato-Yané 1981 \\
\hline Xyophorus & 15.1 & 56.5 & 63.9 & 62.1 & 1.13 & 1.10 & 35.0 & Brandoni 2014 \\
\hline Megathericulus & 276.1 & 333.2 & 346.5 & 351.1 & 1.04 & 1.05 & 33.6 & Pujos et al. 2013 \\
\hline Diabolotherium & 131.4 & 143.8 & 163.6 & 154.7 & 1.14 & 1.08 & 35.4 & Pujos et al. 2007 \\
\hline Pseudoglyptodon & 50.3 & 31.9 & 41.7 & 47.9 & 1.31 & 1.50 & 34.3 & Engelmann 1987 \\
\hline Baraguatherium & - & 252.7 & 285.8 & 222.9 & 1.13 & 0.88 & 37.5 & Rincón et al. 2017 \\
\hline Aymaratherium & 33.8 & 172.1 & 185.9 & 159.3 & 1.08 & 0.93 & 35.9 & Pujos et al. 2016 \\
\hline Australonyx & 152.1 & 283.8 & 302.4 & 305.8 & 1.07 & 1.08 & 33.9 & De Iuliis et al. 2009 \\
\hline Lakukullus & 34.7 & 129.8 & 153.8 & 172.8 & 1.19 & 1.33 & 33.7 & Pujos et al. 2014 \\
\hline Prepotherium & 25.6 & 65.5 & 66.1 & 69.7 & 1.01 & 1.06 & 32.8 & Scott 1904 \\
\hline Bradypus & 7.8 & 12.0 & 13.2 & 16.8 & 1.10 & 1.40 & 31.4 & This work* \\
\hline Choloepus & 31.6 & 16.8 & 17.8 & 21.7 & 1.05 & 1.29 & 31.6 & This work* \\
\hline
\end{tabular}

* Measurements taken from computerised tomography in digimorph.org. 
recognized for a long time (Felsenstein 1985). In fact, some studies have used phylogenetic comparative methods to study the IC model in some groups (Bernal et al. 2013, Carter and Worthington 2016). In the present study, we employed PGLS to address the existence of the IC model in sloths. Specifically, we used the function corPagel from the package ape (Paradis and Schliep 2018) to define a correlation structure derived from Brownian motion allowing lambda to be estimated by the function. Also, we accounted for unequal tip variances due to a non-ultrametric tree. The OLS and RMA models were fitted using the software Past (Hammer et al. 2001), while the PGLS models were fitted using the package nlme (Pinheiro et al. 2012) for the software R (R core team 2019). In order to contemplate the phylogenetic relationships among the studied sloths, we used the phylogenetic framework previously used by Delsuc et al. (2019) for the study of the ancestral reconstruction of the dental configuration. For this, we used a backbone constraint based on Delsuc et al. (2019) molecular results on the morphological phylogeny proposed by Varela et al. (2018).

First, we evaluated the existence of the IC in all the data. However, we further tested the model after the exclusion of Octodontotherium, as this taxon was clearly an outlier when the data were plotted (see Text-fig. 4). The placement of this taxon could be explained by the unclear relationship of orophodontids with the rest of sloths and, therefore, the potential inexistence of homologies among their teeth. Alternatively, we tested the existence of an IC in the first three teeth of sloths, i.e., the first caniniform/molariform and the subsequent $\mathrm{mfl}$ and $\mathrm{mf} 2$, to account for the existence of a different pattern as well as the potential influence of the first tooth on the last three teeth.

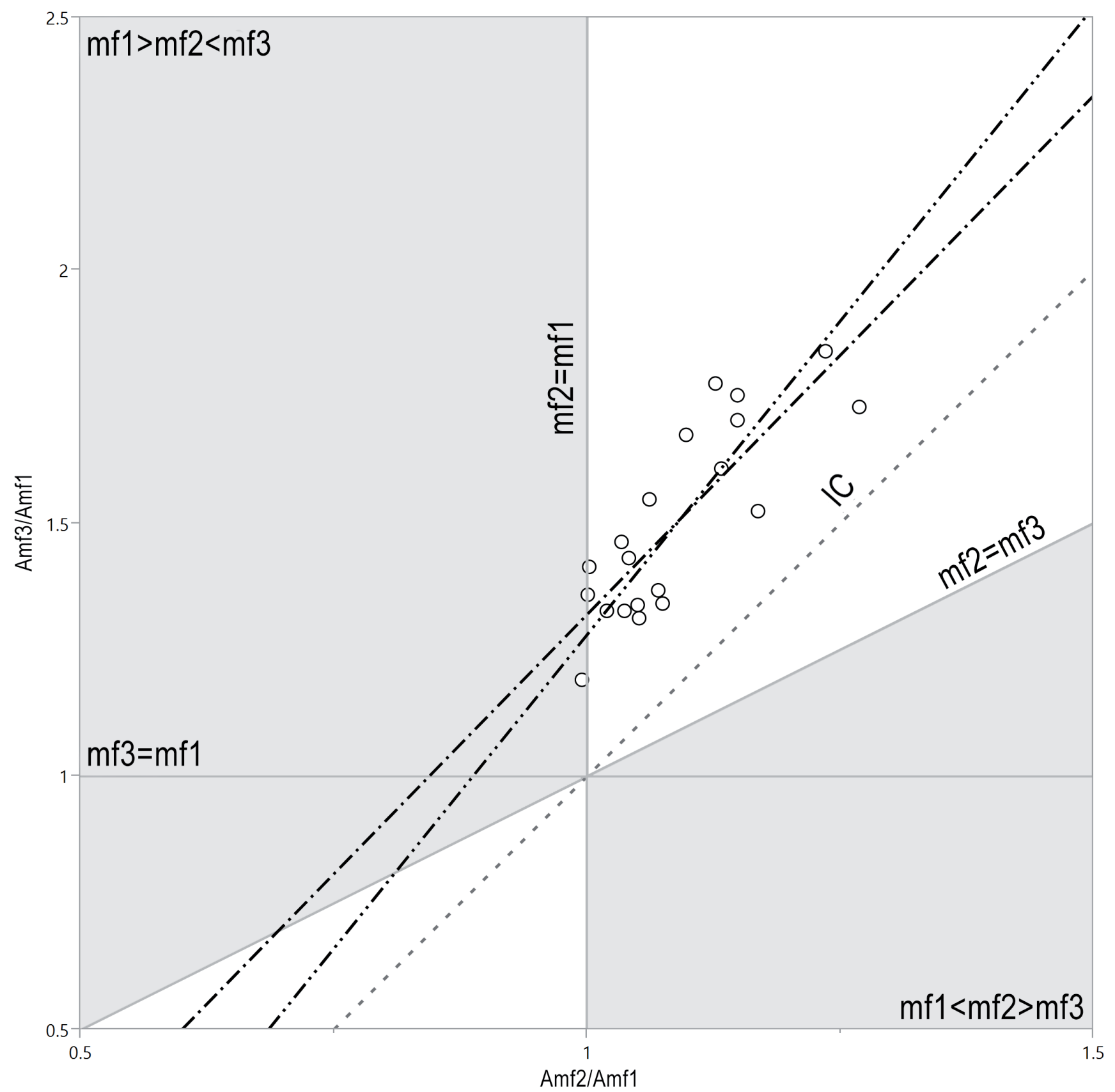

Text-fig. 2. Developmental morphospace of molariform ratios in Lestodon armatus compared to the IC model. Dash-dot line (---), show OLS line; dash double-dot line (-..-) shows RMA line. 
Furthermore, considering that the inhibitory cascade model predicts that the tooth placed in the middle should occupy $1 / 3$ of the sum of the occlusal area, we calculated this value for each family and tested for significant differences with ANOVA and Tukey's multiple comparisons test $(\mathrm{p}<0.05)$.

Finally, based on Tukey's test, we evaluated the possibility of different families showing different patterns regarding the existence and intensity of the IC model. For this, we included families as a categorical variable and compare different models using AIC.

\section{Results}

\section{Lestodon armatus}

A significant positive correlation $\left(\mathrm{r}^{2}=0.66, \mathrm{p}<0.01\right)$ was found between the ratios of $\mathrm{mf} 2$ and $\mathrm{mfl}$, and $\mathrm{mf} 3$ and $\mathrm{mf1}$ in L. armatus. Regarding the IC model predictions, the regression analysis showed a slope of 2.05 (CI: 1.13-2.54) for OLS and 2.48 (CI: 1.38-3.05) for RMA, and an intercept of -0.73 (CI: $-1.26-0.22$ ) for OLS and -1.20 (CI: $-1.82-$ 0.02) for RMA, consistent with the IC model (Text-fig. 2). However, the results indicate that, even if L. armatus comply with the IC model, some specimens almost fall outside the strict IC model prediction, with $\mathrm{mf1}$ and $\mathrm{mf} 3$ larger than $\mathrm{mf} 2$. When observing the different specimens of L. armatus in detail, it is evident that the $\mathrm{mf} 3$ is always the largest tooth (even in juvenile specimens), while $\mathrm{mfl}$ and $\mathrm{mf} 2$ show more variability and overlap in their size (Text-fig. 3). On the other hand, the mf 2 occupied roughly $30 \%$ on average among the studied individuals, well below the prediction of the IC model. Alternatively, considering the great variability in the caniniform size in this taxon, a preliminary test (data not shown) exploring the existence of an IC among the first three teeth with a lower sample showed a significant correlation and a slope of 1 , clearly inconsistent with the IC model.

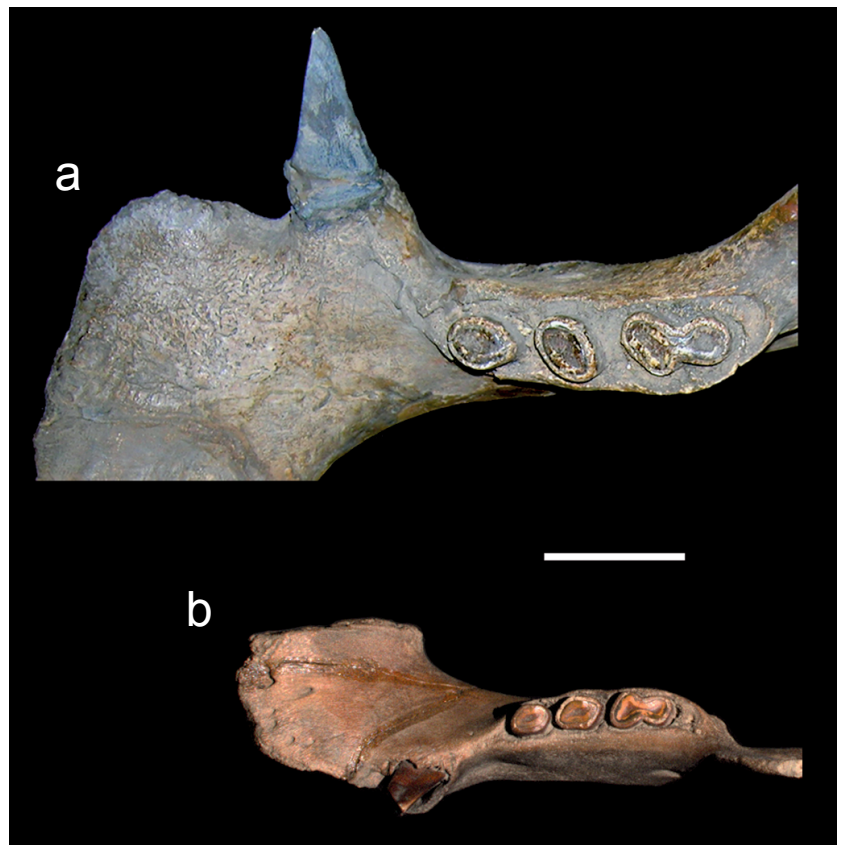

Text-fig. 3. Mandibles of (a) adult (MACN 10830) and (b) juvenile (CAV 898) specimens of Lestodon armatus. Scale bar $5 \mathrm{~cm}$.

\section{Sloths}

Regarding the data set that includes taxa from all the families of sloths, a significant correlation was found between the ratios (Slope: 0.84 [0.53-1.15]; Intercept: 0.37 [-0.15$\left.0.88], \mathrm{r}^{2}=0.63, \mathrm{p}<0.01\right)$. However, although roughly $85 \%$ of the studied sloth genera fall inside the area predicted by de IC model, the regression results are not consistent with the IC model. However, considering the plotted data (Textfig. 4), it is evident that only one taxon falls well outside the IC model predicted area. In fact, the exclusion of this single taxon (Octodontotherium) significantly changes the obtained regression (Slope: 1.88 [1.37-2.39]; Intercept: $\left.-0.87[-1.55-(-0.20)], \mathrm{r}^{2}=0.75, \mathrm{p}<0.01\right)$, producing results largely consistent with the IC model.

Furthermore, when testing the existence of a similar pattern between the first three teeth (Text-fig. 5), the results show much less spread of the data (although, again, Octodontotherium falls considerably away from the rest of the taxa) as well as the lack of a pattern expected by the existence of IC (Slope: 1.11 [1.00-1.21]; Intercept: 0.05 $\left.[-0.16-0.27], \mathrm{r}^{2}=0.90, \mathrm{p}<0.01\right)$.

Moreover, the $\mathrm{mf} 2$ roughly occupied $1 / 3$ of the tooth row in all sloth families, but values in Mylodontidae were significantly lower $(p<0.05)$ than in the rest of the families while the values of the orophodontids were considerably higher than most other taxa (Tab. 3, Text-fig. 6).

Considering the spread of the data, as well as the results of the Tukey's post-hoc test, we tested the existence of different patterns among families. The results (Tab. 4) showed support for models taking mylodontids and orophodontids separately. The most supported model was the one with different regressions for mylodontids, orophodontids, and the rest of the sloths. In that case, the mylodontids showed a pattern consistent with the IC model, with a slope moderately higher than 2 (Slope: 2.88 [1.923.84]; Intercept: $\left.-1.52[-2.05-(-0.99)], \mathrm{r}^{2}=0.70, \mathrm{p}<0.01\right)$ which is consistent with the $\mathrm{mf} 1 \leq \mathrm{mf} 2<<\mathrm{mf} 3$ pattern. In particular, the Scelidotheriinae Catonyx and Valgipes were placed outside the area predicted by the IC model, showing an $\mathrm{mf1}>\mathrm{mf} 2<\mathrm{mf} 3$ configuration. On the other hand, the orophodontids showed a pattern inconsistent with the IC, with a slope slightly below 1 (Slope: 0.78 [0.63-0.93]; Intercept: $\left.0.12[-0.15-0.39], \mathrm{r}^{2}=0.69, \mathrm{p}<0.01\right)$. Specifically, it is worth noting that the orophodontids represented the taxa that fell most distant from the area expected by the IC, with Octodontotherium, Octodontobradys, and Baraguatherium showing an $\mathrm{mf1}<\mathrm{mf} 2>\mathrm{mf} 3$ configuration. The rest of the sloth taxa from the other families showed values almost consistent with the IC model and similar to values previously reported in other taxa where the IC model is present (see Tab. 5), with a slope below 2 but well above 1 (Slope: 1.57 [1.56-1.58]; Intercept: -0.54 [-0.71$\left.(-0.37)], \mathrm{r}^{2}=0.80, \mathrm{p}<0.01\right)$. Also, it is worth mentioning the placement of two Nothrotheriidae, Aymaratherium and Mionothropus, which fell well outside the predicted area with $\mathrm{mf} 1<\mathrm{mf} 2>\mathrm{mf} 3$ and $\mathrm{mf} 1>\mathrm{mf} 2<\mathrm{mf} 3$ configurations, respectively. Table 5 shows the comparisons of the obtained results in the regression analyses with the strict IC model prediction and previously obtained results in other mammalian groups. 


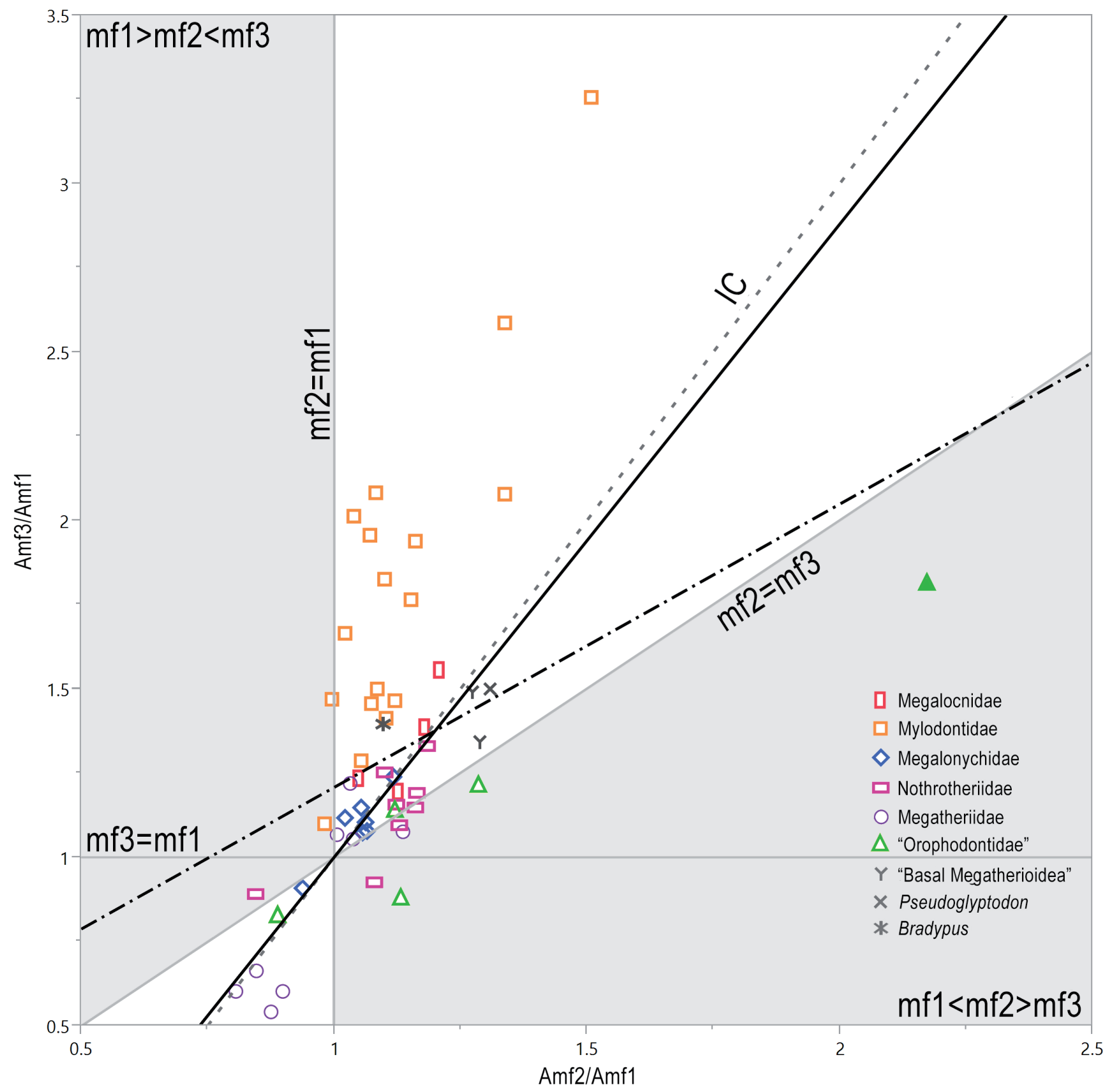

Text-fig. 4. Macroevolutionary trends related to the IC model in the last three teeth of the six families of extinct sloths, as well as specimens of the "basal Megatherioidea", Pseudoglyptodon, and Bradypus. Dash-dot line (-.-) shows the regression including all data; solid line shows the regression after the exclusion of Octodontotherium (shown in the plot as a filled triangle).

\section{Discussion}

\section{The inhibitory cascade in sloths}

The inhibitory cascade has been proven to be present in many groups of extant mammals, such as rodents, carnivorans, and primates, as well as extinct ungulates and Mesozoic basal mammals (Kavanagh et al. 2007, Polly 2007, Labonne et al. 2012, Wilson et al. 2012, Asahara 2013, Bernal et al. 2013, Halliday and Goswami 2013, Schroer and Wood 2015, Asahara et al. 2016, Evans et al. 2016, Gomes Rodrigues et al. 2017). In this work, we demonstrate that it is also present in at least one group of Xenarthrans, the Folivora, even with the many peculiarities in the dentition of the group: tooth loss, enamel loss, homodonty, and changes in the typical mammalian dental formula, among others.

In Lestodon armatus, our results show that the observed variability largely complies with the IC predictions. In this sloth, the last molariform is always the largest tooth in the series, but the $\mathrm{mfl}$ and $\mathrm{mf} 2$ are similar in size, with some specimens with $\mathrm{mf1}$ approximately equal to $\mathrm{mf}$. This variation could be related to ontogeny, with juvenile specimens having larger $\mathrm{mfl}$, but $\mathrm{mf} 2$ and $\mathrm{mf} 3$ increasing in relative size during ontogeny. However, this pattern is not clear since many adult individuals present similarly sized $\mathrm{mf1}$ and $\mathrm{mf} 2$ (Text-fig. 3) and the juvenile individuals were not clustered in any zone of the morphospace.

For all sloths, the existence of the IC in the last three teeth is largely supported in the clade. However, as mentioned 


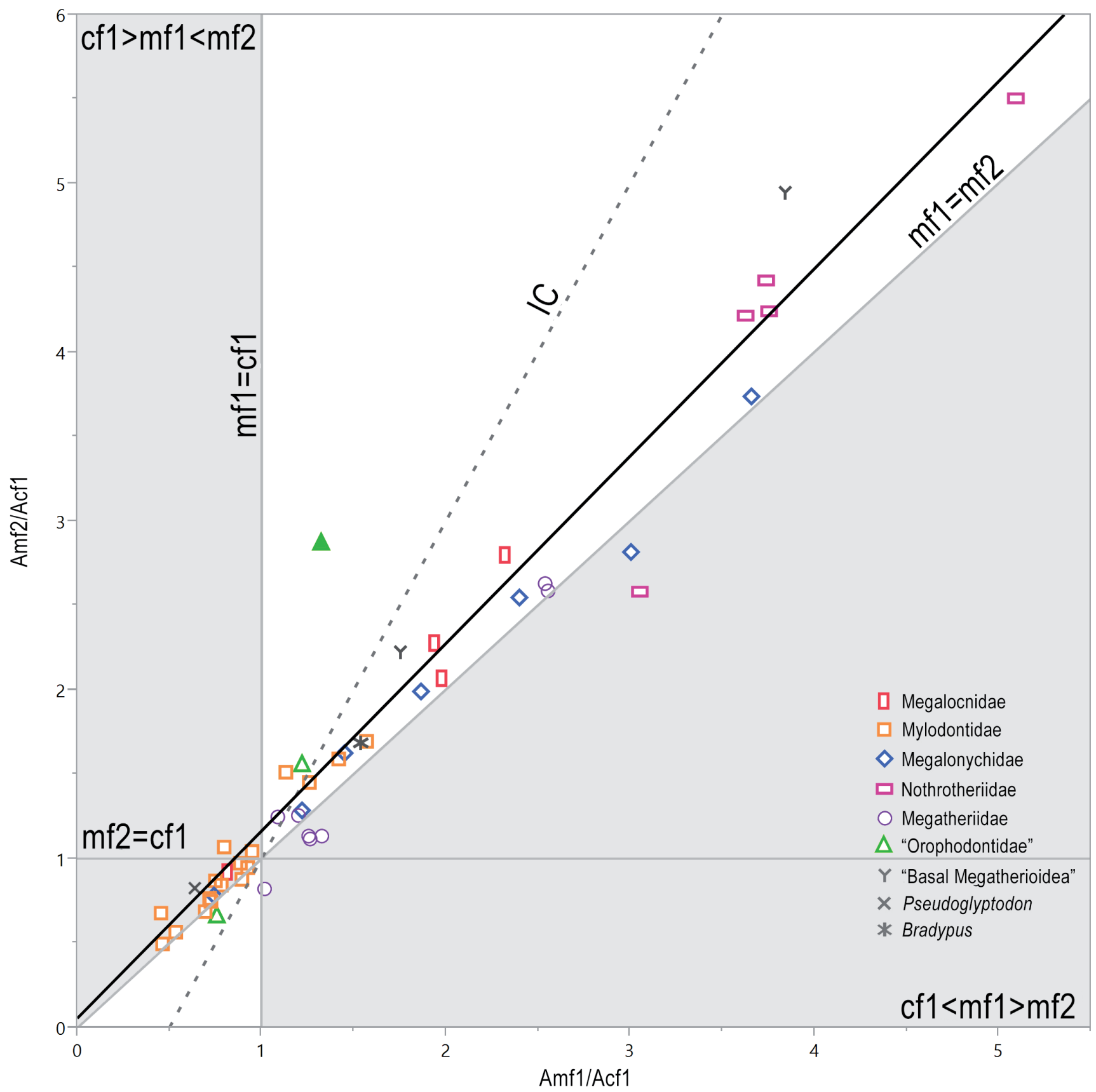

Text-fig. 5. Macroevolutionary trends related to the IC model in the first three teeth of the six families of extinct sloths, as well as specimens of the "basal Megatherioidea", Pseudoglyptodon, and Bradypus. Dashed line ( - - ) shows the regression including all data; solid line shows the regression after the exclusion of Octodontotherium (shown in the plot as a filled triangle).

before, the placement of one genus, Octodontotherium, as a clear outlier, required its exclusion to obtain significant results. Contrarily, a pattern consistent with the prediction of the IC model was not recovered for the first three teeth regardless of the first tooth morphology (caniniform or molariform).

Furthermore, significant differences were obtained between families when considering the area of $\mathrm{mf}$, with mylodontids and orophodontids respectively having an $\mathrm{mf} 2$ considerably smaller or larger than expected under the IC model. These differences were further explored after the evaluation of different slopes in these families. A slight departure from the strict prediction of the IC model was detected in the case of mylodontids. In this family, especially in mylodontines, a slope considerably larger than 2 was obtained between the molariform ratios, showing a pattern in which $\mathrm{mf3}$ tends to be remarkably larger while $\mathrm{mfl}$ and $\mathrm{mf} 2$ remain smaller and sometimes similar in size. In fact, some mylodontids, namely Catonyx and Valgipes, showed an $\mathrm{mf1}>\mathrm{mf} 2<\mathrm{mf3}$ configuration, which was proposed by Kavanagh et al. (2007) as the developmentally least likely phenotype to occur. For orophodontids, the slope was slightly lower than 1, showing a significant departure from thee IC model. However, as observed in Text-fig. 5, a pattern consistent with the IC model could be present in the first three teeth in orophodontids, but this cannot be confirmed with the current data due to the poor preservation or absence of $\mathrm{cf} 1$ in the specimens. These trends in orophodontids could be the result of different dental homologies in this clade compared with the rest of sloths. Nonetheless, a similar 


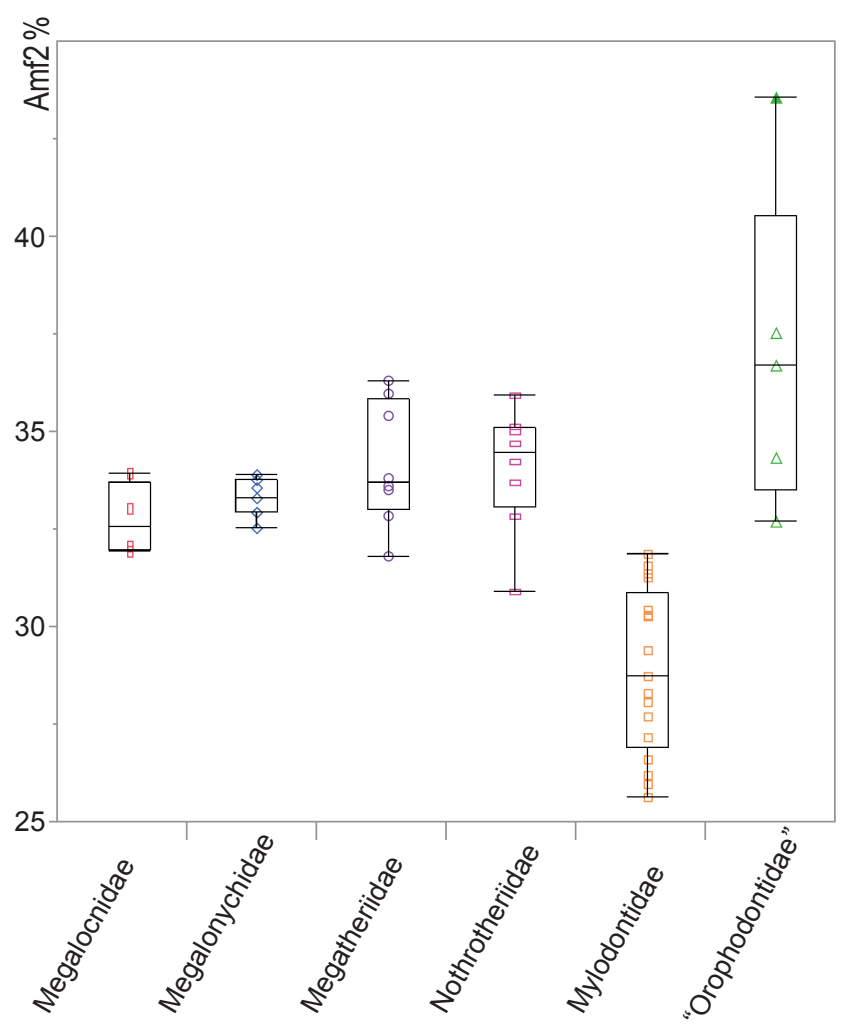

Text-fig. 6. Boxplots showing the proportion of $\mathrm{mf} 2$ in relation to the sum of the occlusal area in the five families of extinct sloths.

pattern was previously reported in ursids, with evidence supporting the existence of a unique IC pattern in this group related to evolutionary changes in the expression or function of low diffusible inhibitory molecules (or their antagonists) affecting $\mathrm{m} 2 / \mathrm{m} 1$, but not $\mathrm{m} 3 / \mathrm{m} 1$ (Asahara et al. 2016). On the other hand, the observed slope after the exclusion of mylodontids and orophodontids showed that most sloths comply with the IC model predictions. Although the observed slope was slightly less steep than the strict prediction of the IC model, it was comparable to those observed in many mammalian groups, including the murine rodents originally studied by Kavanagh et al. (2007).

Even though the molariform loci of sloths seem not to be homologous with those of molars of other mammalian groups, the existence of the IC allows observing that the mechanisms described for other clades are probably also

Table 3. Proportion of the $\mathrm{mf} 2$ relative to the three last molariforms in sloths. Levels not connected by the same letters are significantly different $(p<0.05)$.

\begin{tabular}{|l|c|c|c|}
\hline Taxon & Mean & SD & \\
\hline All sloths & 0.32 & 0.03 & - \\
\hline Megalocnidae & 0.33 & 0.01 & $\mathrm{~B}$ \\
\hline Megalonychidae & 0.33 & 0.01 & $\mathrm{~B}$ \\
\hline Megatheriidae & 0.34 & 0.02 & $\mathrm{AB}$ \\
\hline Nothrotheriidae & 0.34 & 0.02 & $\mathrm{AB}$ \\
\hline Mylodontidae & 0.29 & 0.02 & $\mathrm{C}$ \\
\hline "Orophodontidae” & 0.37 & 0.04 & $\mathrm{~A}$ \\
\hline
\end{tabular}

working during the development of the molariforms of sloths and constraining the evolution of relative tooth sizes. In this regard, it must be pointed out that only the $\mathrm{mf} 3$ of sloths would be homologous to a molar, particularly the $\mathrm{m} 1$ (Hautier et al. 2016), but the observed pattern across relative tooth sizes clearly indicates the influence of the front teeth on the hind teeth (i.e., the IC). On the other hand, premolars in mammals originate from back to front (unlike molars, which develop from front to back; Luckett 1993, van Nievelt and Smith 2005), and their influence over other teeth is not extensively studied.

However, Labonne et al. (2012) found that the p4, when present, significantly influences the IC in rodents, constraining the development of $\mathrm{m} 1$ and affecting molars relative sizes. Furthermore, Evans et al. (2016) results indicate the existence of an expanded IC in hominins affecting all primary post-canine dentition, namely the deciduous premolars and molars. In most mammals, including hominins, these deciduous premolars are replaced by permanent premolars, so many studies are commonly based on this permanent dentition (Dahlberg 1945, Townsend and Brown 1981). However, sloths (and most xenarthrans) do not show tooth replacement and their $\mathrm{mf} 1$ and $\mathrm{mf} 2$ are probably homologous to the dp3 and dp4 of most mammals (see Hautier et al. 2016). Thus, the observed pattern in the molariforms ratios in sloths could be related to the existence of a similar IC pattern to that in hominins, in which the development of all present postcanine teeth is governed by the equilibrium between activation and inhibition between teeth, with the peculiarity that sloths would have lost their last two molars. Also, the clearly different IC pattern in mylodontids could be related to changes in inhibition and activation intensities along the cascade, in particular, an extreme activation of the $\mathrm{mf3}$ development. However, considering the limited information regarding tooth development in fossil sloths, differences in tooth homologies in the case of mylodontids should not be ruled out. Moreover, given the fact that the first lower tooth (the caniniform in most sloths) seems to be a dp2, its potential effects over the IC should be taken into account, especially in cases where it shows a molariform morphology.

Finally, it must be mentioned that in most sloths the upper dentition has one more tooth, although according to the previously mentioned developmental studies the extra tooth is the first one and the last three molariforms still would be homologous to the $\mathrm{dp} 3, \mathrm{dp} 4$, and $\mathrm{m} 1$ of other mammals. However, in many sloths, including many in which the last lower tooth is the largest in the series, the last upper tooth is the smallest in the series. This apparent difference between upper and lower dentition regarding the trends in relative tooth sizes will be further studied in future research in order to explore differences between inhibition and activation intensities in both toothrows, a topic scarcely explored in previous works (Gomes Rodrigues et al. 2017).

\section{IC and dietary adaptations in fossil sloths}

Several authors reported variations in the IC model among taxa that related to different dietary adaptations. In rodents, an increase in the relative sizes of $\mathrm{m} 2$ and $\mathrm{m} 3$ led to an $\mathrm{m} 1=\mathrm{m} 2=\mathrm{m} 3$ configuration that was related to 


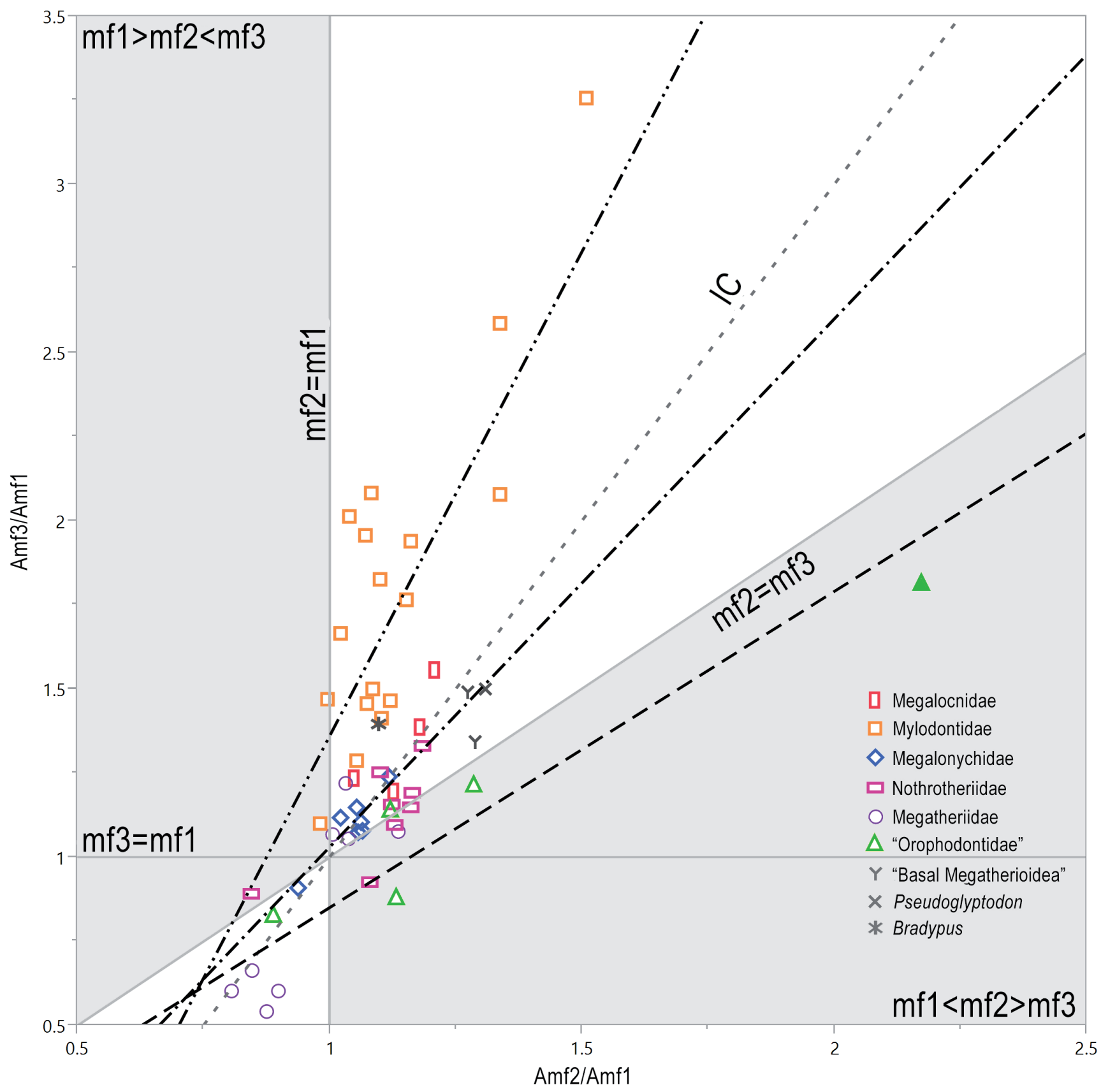

Text-fig. 7. PGLS regressions for Mylodontidae, "Orophodontidae", and the rest of the sloths considered separately, Mylodontidae: dash double-dot line (-..-), “Orophodontidae": dash-dot line (-.-), rest of sloths: dash line (--).

more herbivorous diets (Kavanagh et al. 2007). Similarly, in canids, insectivorous and omnivorous taxa showed relatively smaller $\mathrm{m} 1$ and larger $\mathrm{m} 2$ and $\mathrm{m} 3$ than taxa with carnivorous habits (Asahara 2013). Moreover, a similar pattern was recovered by Halliday and Goswami (2013) for 135 genera from several extinct mammalian taxa, with more faunivorous taxa arranged in the bottom left of the morphospace and more herbivorous taxa in the top right.

In the case of sloths, the only proposed major group with dietary adaptations more related to bulk feeding or

Table 4. Model support of the regression models fitted to the sloth molariform ratios.

\begin{tabular}{|c|c|c|c|}
\hline Model & AICc & $\Delta \mathrm{AICc}$ & AICcw \\
\hline All families considered separately & 3.96 & 10.41 & 0.005 \\
\hline Mylodontidae and "Orophodontidae" considered separately & -6.45 & $\mathbf{0}$ & 0.994 \\
\hline Mylodontidae considered separately & 32.15 & 38.6 & $<0.001$ \\
\hline "Orophodontidae" considered separately & 7.88 & 14.33 & 0.001 \\
\hline All data & 29.38 & 35.83 & $<0.001$ \\
\hline
\end{tabular}


Table 5. PGLS regression analysis of sloth molariform ratios compared to previously published results in other mammalian groups.

\begin{tabular}{|l|c|c|c|c|c|c|c|}
\hline & Slope & C.I. min & C.I. max & Intercept & C.I. min & C.I. max & r \\
\hline IC model & 2 & - & - & 0 & - & - & 1 \\
\hline Murinae (Kavanagh et al. 2007) & 2.15 & 1.77 & 2.69 & -1.22 & -1.65 & -0.93 & 0.74 \\
\hline Arvicolinae (Renvoisé et al. 2009) & 1.39 & 1.21 & 1.56 & -0.31 & -0.41 & -0.21 & 0.77 \\
\hline Carnivora (Asahara 2013) & 0.59 & 0.49 & 0.74 & -0.17 & -0.22 & -0.13 & 0.62 \\
\hline Astrapotheria (Wilson et al. 2012) & 1.27 & 1.06 & 1.48 & -0.29 & -0.55 & -0.04 & 0.91 \\
\hline Notoungulata (Wilson et al. 2012) & 1.76 & 1.58 & 1.99 & -0.66 & -0.88 & -0.46 & 0.81 \\
\hline Creodonta (Asahara et al. 2016) & 2.57 & 1.30 & 7.25 & -2.31 & -8.59 & -0.72 & 0.39 \\
\hline Dasyuromorphia (Asahara et al. 2016) & 2.01 & 1.88 & 3.20 & -1.31 & -2.90 & 0.27 & 0.70 \\
\hline Folivora & 0.84 & 0.53 & 1.15 & 0.37 & -0.15 & 0.88 & 0.63 \\
\hline Folivora excluding Octodontotherium & 1.88 & 1.37 & 2.39 & -0.87 & -1.55 & -0.20 & 0.75 \\
\hline Mylodontidae & 2.88 & 1.92 & 3.84 & -1.52 & -2.05 & -0.99 & 0.70 \\
\hline “Orophodontidae" & 0.78 & 0.63 & 0.93 & 0.12 & -0.15 & 0.39 & 0.69 \\
\hline Folivora excluding Mylodontidae and “Orophodontidae” & 1.57 & 1.56 & 1.58 & -0.54 & -0.71 & -0.37 & 0.80 \\
\hline
\end{tabular}

grazing are mylodontids, with some members of the family exhibiting these adaptations as early in the fossil record as the Oligocene (Bargo and Vizcaíno 2008, Shockey and Anaya 2011, Pujos et al. 2012). Considering our results, these adaptations could be related to the remarkable departure from the strict expected relative teeth sizes under the IC model, with mylodontids, especially mylodontines, showing an $\mathrm{mf1} \leq \mathrm{mf} 2<<\mathrm{mf} 3$ configuration. In this case, the $\mathrm{mf} 2$ occupies $\sim 29 \%$ on average, while the $\mathrm{mf} 3$ occupies $\sim 45 \%$ of the molariform area.

On the other hand, all other sloths have been commonly interpreted as browsers, and they are mainly placed in the centre of the morphospace. However, it is particularly interesting that some megatheriids, specifically the largest megatheriines, were placed in the other extreme of the morphospace in the left bottom part of the graph, with almost all members having an $\mathrm{mf} 1>\mathrm{mf} 2>\mathrm{mf} 3$ configuration. As mentioned above, this part of the morphospace is associated with less herbivorous diets, with many omnivorous, insectivorous, and carnivorous taxa showing similar configurations. Interestingly, the giant megatheriine sloth Megatherium americanum from southern South America has so far been the only species with a proposed not strictly herbivorous diet (Fariña 1996, Fariña and Blanco 1996, Fariña and Varela 2018; see also Bargo 2001b). However, other evidence also suggests an herbivorous diet for this sloth (Green and Kalthoff 2015, Bocherens et al. 2017) and other developmental or morphofunctional reasons should not be discarded. In particular, the dental formula of megatheriines, with the first tooth having a molariform morphology in contrast to the caniniform present in most other sloths, could have affected the IC and should be further studied.

\section{Conclusions}

Our results show that, despite having extremely derived dentitions among mammals, sloths dental development is largely constrained by the same mechanisms acting in many other mammalian clades. At the same time, these mechanisms were important during the evolution of the group and, in part, produced the diversity of morphologies found in extinct and extant sloths. Moreover, important departures of the strictly expected morphology under the IC model seem to have allowed some sloths, specifically some mylodontids, a dentition arrangement better suited to grazing.

The previous findings regarding the development of teeth in extant sloths (Hautier et al. 2016), coupled to the analysis of the abundant extinct diversity of a group with only two extant genera, allowed us to test an important developmental model in a macroevolutionary context in a group of mammals in which the presence of the IC affecting tooth proportions would be considered improbable at first glance.

\section{Acknowledgements}

We would like to thank Andrés Rinderknecht (Museo Nacional de Historia Natural), Alejandro Kramarz (Museo Argentino de Ciencias Naturales "Bernardino Rivadavia"), Marcelo Reguero (Museo de La Plata), and the personnel of the museums of Colonia del Sacramento, Uruguay, for access to the collections under their care. This study was partially funded by the Agencia Nacional de Investigación e Innovación, grants POS_FCE_2015_1_1005196 and FCE_1_2014_1_104572, and a scholarship from the Comisión Académica de Posgrado, UdelaR. We are also indebted to National Geographic, grant $N^{\circ} 178431$. We would like to thank Thomas Halliday and an anonymous reviewer for their constructive comments that greatly improved this work. Finally, we are grateful to the editorial team, Ivan Horáček, Irina Ruf, Thomas Lehmann, and Lutz Christian Maul, for the invitation to participate in this Festschrift in memory of Gerhard Storch.

\section{References}

Asahara, M. (2013): Unique inhibitory cascade pattern of molars in canids contributing to their potential to evolutionary plasticity of diet. - Ecology and Evolution, 3(2): 278-285.

https://doi.org/10.1002/ece3.436 
Asahara, M., Saito, K., Kishida, T., Takahashi, K., Bessho, K. (2016): Unique pattern of dietary adaptation in the dentition of Carnivora: its advantage and developmental origin. - Proceedings of the Royal Society, B, 283(1832): 20160375 (10 pp.).

https://doi.org/10.1098/rspb.2016.0375

Bargo, M. S. (2001a): El aparato masticatorio de los perezosos terrestres (Xenarthra, Tardigrada) del Pleistoceno de la Argentina. Morfometría y biomecánica [The masticatory apparatus of the ground sloths (Xenarthra, Tardigrada) from the Pleistocene of Argentina]; $\mathrm{PhD}$ thesis. - MS, Universidad Nacional de La Plata, La Plata, Argentina, 400 pp. (in Spanish) (copy in Library of Museo de La Plata)

Bargo, M. S. (2001b): The ground sloth Megatherium americanum: skull shape, bite forces, and diet. - Acta Palaeontologica Polonica, 46(2): 173-192.

Bargo, M. S., Vizcaíno, S. F. (2008): Paleobiology of Pleistocene ground sloths (Xenarthra, Tardigrada): biomechanics, morphogeometry and ecomorphology applied to the masticatory apparatus. - Ameghiniana, 45(1): 175-196.

Bernal, V., González, P. N., Pérez, S. I. (2013): Developmental processes, evolvability, and dental diversification of New World monkeys. - Evolutionary Biology, 40(4): 532-541. https://doi.org/10.1007/s11692-013-9229-4

Bocherens, H., Cotte, M., Bonini, R. A., Straccia, P., Scian, D., Soibelzon, L., Prevosti, F. J. (2017): Isotopic insight on paleodiet of extinct Pleistocene megafaunal Xenarthrans from Argentina. - Gondwana Research, 48(1): 7-14. https://doi.org/10.1016/j.gr.2017.04.003

Brandoni, D. (2011): The Megalonychidae (Xenarthra, Tardigrada) from the late Miocene of Entre Ríos Province, Argentina, with remarks on their systematics and biogeography. - Geobios, 44(1): 33-44.

https://doi.org/10.1016/j.geobios.2010.06.005

Brandoni, D. (2014): “Xyophorus" sp. en el Mioceno Medio de Chubut: implicancias sistemáticas, biogeográficas y biocronológicas del registro de un Nothrotheriinae en el Neógeno de la Argentina ["Xyophorus" sp. in the Middle Miocene of Chubut: systematic, biogeographical and biochronological implications of the record of a Nothrotheriinae in the Neogene of Argentina]. - Ameghiniana, 51(2): 94-105. (in Spanish) https://doi.org/10.5710/AMEGH.05.12.2013.1267

Brandoni, D., Powell, J. E., González, O. E. (2011): Anisodontherium from the late Miocene of north-western Argentina. - Acta Palaeontologica Polonica, 57(2): 241-249. https://doi.org/10.4202/app.2010.0129

Butler, P. M. (1939): Studies of the mammalian dentition differentiation of the post-canine dentition. - Proceedings of the Zoological Society of London, 109(1): 1-36. https://doi.org/10.1111/j.1469-7998.1939.tb00021.x

Carlini, A. A., Brandoni, D., Dal Molin, C. N. (2013): A new genus and species of Planopinae (Xenarthra: Tardigrada) from the Miocene of Santa Cruz Province, Argentina. Zootaxa, 3694(6): 565-578. https://doi.org/10.11646/zootaxa.3694.6.4

Carlini, A. A., Brandoni, D., Sánchez, R. (2006): First Megatheriines (Xenarthra, Phyllophaga, Megatheriidae) from the Urumaco (Late Miocene) and Codore (Pliocene) Formations, Estado Falcón, Venezuela. - Journal of Systematic Palaeontology, 4(3): 269-278.

https://doi.org/10.1017/S1477201906001878

Carlini, A. A., Brandoni, D., Scillato-Yané, G. J., Pujos, F. (2002): Una nueva especie de megaterino (Xenarthra, Megatheriidae) del Mioceno tardío-Plioceno de Catamarca, Argentina [A new species of megatherine (Xenarthra, Megatheriinae) from the late Miocene-Pliocene of Catamarca, Argentina]. - Ameghiniana, 39(3), 367-377. (in Spanish)

Carlini, A. A., Scillato-Yané, G. J., Sánchez, R. (2006): New Mylodontoidea (Xenarthra, Phyllophaga) from the Middle Miocene-Pliocene of Venezuela. - Journal of Systematic Palaeontology, 4(3): 255-267. https://doi.org/10.1017/S147720190600191X

Cartelle, C., De Iuliis, G., Ferreira, R. L. (2009): Systematic revision of tropical Brazilian scelidotheriine sloths (Xenarthra, Mylodontoidea). - Journal of Vertebrate Paleontology, 29(2): 555-566. https://doi.org/10.1671/039.029.0231

Cartelle, C., De Iuliis, G., Pujos, F. (2008): A new species of Megalonychidae (Mammalia, Xenarthra) from the quaternary of Poço Azul (Bahia, Brazil). - Comptes Rendus Palevol, 7(6): 335-346.

https://doi.org/10.1016/j.crpv.2008.05.006

Carter, K. E., Worthington, S. (2016): The evolution of anthropoid molar proportions. - BMC Evolutionary Biology, 16(1): 110 (18 pp.).

https://doi.org/10.1186/s12862-016-0673-5

Christiansen, P., Fariña, R. A. (2003): Mass estimation of two fossil ground sloths (Xenarthra; Mylodontidae). In: Fariña, R. A., Vizcaíno, S. F., Storch, G. (eds), Morphological studies in fossil and extant Xenarthra (Mammalia). Senckenbergiana biologica, 83(1): 95-101.

Dahlberg, A. A. (1945): The changing dentition of man. The Journal of the American Dental Association, 32(11): 676-690. https://doi.org/10.14219/jada.archive.1945.0112

De Iuliis, G., Gaudin, T. J., Vicars, M. J. (2011): A new genus and species of nothrotheriid sloth (Xenarthra, Tardigrada, Nothrotheriidae) from the late Miocene (Huayquerian) of Peru. - Palaeontology, 54(1): 171-205. https://doi.org/10.1111/j.1475-4983.2010.01001.x

De Iuliis, G., Pujos, F., Cartelle, C. (2009): A new ground sloth (Mammalia: Xenarthra) from the Quaternary of Brazil. - Comptes Rendus Palevol, 8(8): 705-715. https://doi.org/10.1016/j.crpv.2009.07.003

De Iuliis, G., Pujos, F., Toledo, N., Bargo, M. S., Vizcaíno, S. F. (2014): Eucholoeops Ameghino, 1887 (Xenarthra, Tardigrada, Megalonychidae) from the Santa Cruz Formation, Argentine Patagonia: implications for the systematics of Santacrucian sloths. - Geodiversitas, 36(2): 209-255. https://doi.org/10.5252/g2014n2a2

Delsuc, F., Kuch, M., Gibb, G. C., Karpinski, E., Hackenberger, D., Szpak, P., Martínez, J. G., Mead, J. I., McDonald, H. G., MacPhee, R. D. E., Billet, G., Hautier, L., Poinar, H. N. (2019). Ancient Mitogenomes Shed Light on the Evolutionary History and Biogeography of Sloths. - Current Biology, 29(1): 1-12. https://doi.org/10.1016/j.cub.2019.05.043 
Dos Santos, J. C. R., Rancy, A., Ferigolo, J. (1993): Octodontobradyinae, uma nova subfamília de Orophodontidae (Edentata, Tardigrada) do Mioceno superior-Plioceno do estado do Amazonas, Brasil [Octodontobradyinae, a new subfamily of Orophodontidae (Edentata, Tardigrada) from the upper Miocene-Pliocene of Amazonas state, Brazil]. - Ameghiniana, 30(3): 255-264. (in Portuguese)

Engelmann, G. F. (1987): A new Deseadan sloth (Mammalia: Xenarthra) from Salla, Bolivia, and its implications for the primitive condition of the dentition in edentates. Journal of Vertebrate Paleontology, 7(2): 217-223. https://doi.org/10.1080/02724634.1987.10011654

Evans, A. R., Daly, E. S., Catlett, K. K., Paul, K. S., King, S. J., Skinner, M. M., Nesse, H. P., Hublin, J.-J., Townsend, G. C., Schwartz, G. T., Jernvall, J. (2016): A simple rule governs the evolution and development of hominin tooth size. - Nature, 530(7591): 477-480. https://doi.org/10.1038/nature16972

Fariña, R. A. (1996): Trophic relationships among Lujanian mammals. - Evolutionary Theory, 11(2): 125-134.

Fariña, R. A., Blanco, R. E. (1996): Megatherium, the stabber. - Proceedings of the Royal Society, B, 263(1377): 1725-1729. https://doi.org/10.1098/rspb.1996.0252

Fariña, R. A., Czerwonogora, A., Di Giacomo, M. (2014): Splendid oddness: revisiting the curious trophic relationships of South American Pleistocene mammals and their abundance. - Anais da Academia Brasileira de Ciências, 86(1): 311-331. https://doi.org/10.1590/0001-3765201420120010

Fariña, R. A., Varela, L. (2018): Comment on "Isotopic insight on paleodiet of extinct Pleistocene megafaunal Xenarthrans from Argentina" by H. Bocherens, M. Cotte, R. A. Bonini, P. Straccia, D. Scian, L. Soibelzon and F. J. Prevosti, Gondwana Research, Volume 48, Issue 1, Pages 7-14. - Gondwana Research, 58: 241-242. https://doi.org/10.1016/j.gr.2018.03.004

Fariña, R. A., Vizcaíno, S. F. (2003): Slow moving or browsers? A note on nomenclature. - In: Fariña, R. A., Vizcaíno, S. F., Storch, G. (eds), Morphological studies in fossil and extant Xenarthra (Mammalia). Senckenbergiana biologica, 83(1): 3-4.

Fariña, R. A., Vizcaíno, S. F., Bargo, M. S. (1998): Body mass estimations in Lujanian (late Pleistocene-early Holocene of South America) mammal megafauna. Mastozoología Neotropical, 5(2): 87-108.

Fariña, R. A., Vizcaíno, S. F., De Iuliis, G. (2013): Megafauna. Giant Beasts of Pleistocene South America. - Indiana University Press, Bloomington, 416 pp.

Fariña, R. A., Vizcaíno, S. F., Storch, G. (eds) (2003): Morphological studies in fossil and extant Xenarthra (Mammalia). - Senckenbergiana biologica, 83(1): 1-101.

Felsenstein, J. (1985): Phylogenies and the comparative method. - The American Naturalist, 125(1): 1-15. https://doi.org/10.1086/284325

Franzen, J. L., Ruf, I., Krystufek, B. (2018): Gerhard Storch, 1939-2017. - Folia Zoologica, 67(2): 124-126.

Gaudin, T. J. (2004): Phylogenetic relationships among sloths (Mammalia, Xenarthra, Tardigrada): the craniodental evidence. - Zoological Journal of the Linnean Society, 140(2): 255-305.

https://doi.org/10.1111/j.1096-3642.2003.00100.x
Gaudin, T. J., Emry, R. J., Wible, J. R. (2009): The phylogeny of living and extinct pangolins (Mammalia, Pholidota) and associated taxa: a morphology based analysis. Journal of Mammalian Evolution, 16(4): 235. https://doi.org/10.1007/s10914-009-9119-9

Gomes Rodrigues, H., Lefebvre, R., Fernández-Monescillo, M., Mamani Quispe, B., Billet, G. (2017): Ontogenetic variations and structural adjustments in mammals evolving prolonged to continuous dental growth. - Royal Society Open Science, 4(7): 170494 (12 pp.). https://doi.org/10.1098/rsos.170494

Green, J. L., Kalthoff, D. C. (2015): Xenarthran dental microstructure and dental microwear analyses, with new data for Megatherium americanum (Megatheriidae). Journal of Mammalogy, 96(4): 645-657. https://doi.org/10.1093/jmammal/gyv045

Halliday, T. J., Goswami, A. (2013): Testing the inhibitory cascade model in Mesozoic and Cenozoic mammaliaforms. - BMC Evolutionary Biology, 13(79): 1-11. https://doi.org/10.1186/1471-2148-13-79

Hammer, Ø., Harper, D. A., Ryan, P. D. (2001): PAST: paleontological statistics software package for education and data analysis. - Palaeontologia electronica, 4(1): 4 (9 pp.).

Hautier, L., Gomes Rodrigues, H., Billet, G., Asher, R. J. (2016): The hidden teeth of sloths: evolutionary vestiges and the development of a simplified dentition. - Scientific Reports, 6: 27763 (9 pp.).

https://doi.org/10.1038/srep27763

Hirschfeld, S. E. (1981): Pliometanastes protistus (Edentata, Megalonychidae) from Knight's Ferry, California with discussion of early Hemphillian Megalonychids. - Museum of Paleontology, University of California, Berkeley, $16 \mathrm{pp}$.

Hirschfeld, S. E. (1985): Ground sloths from the Friasian La Venta fauna, with additions to the Pre-Friasian Coyaima fauna of Colombia, South America. - University of California publications in geological sciences, 128: 1-91.

Hoffstetter, R. (1954): Les gravigrades cuirassés du Déséadien de Patagonie [The armoured gravigrades from the Deseadan of Patagonia]. - Mammalia, 18(2): 159-169. (in French) https://doi.org/10.1515/mamm.1954.18.2.159

Hunter, J. P., Janis, C. M. (2006): Spiny Norman in the Garden of Eden? Dispersal and early biogeography of Placentalia. - Journal of Mammalian Evolution, 13(2): 89-123. https://doi.org/10.1007/s10914-006-9006-6

Kavanagh, K. D., Evans, A. R., Jernvall, J. (2007): Predicting evolutionary patterns of mammalian teeth from development. - Nature, 449(7161): 427-432. https://doi.org/10.1038/nature06153

Labonne, G., Laffont, R., Renvoisé, E., Jebrane, A., Labruère, C., Chateau-Smith, C., Navarro, N., Montuire, S. (2012): When less means more: evolutionary and developmental hypotheses in rodent molars. - Journal of Evolutionary Biology, 25(10): 2102-2111. https://doi.org/10.1111/j.1420-9101.2012.02587.x

Luckett, W. P. (1993): Ontogenetic staging of the mammalian dentition, and its value for assessment of homology and heterochrony. - Journal of Mammalian Evolution, 1(4): 269-282. https://doi.org/10.1007/BF01041667 
Matthew, W. D., de Paula Couto, C. (1959): The Cuban edentates. - Bulletin of American Museum of Natural History, 117: 1-56.

McAfee, R. K. (2009): Reassessment of the cranial characters of Glossotherium and Paramylodon (Mammalia: Xenarthra: Mylodontidae). - Zoological Journal of the Linnean Society, 155(4): 885-903.

https://doi.org/10.1111/j.1096-3642.2008.00468.x

McDonald, H. G. (2003): Xenarthran skeletal anatomy: primitive or derived? (Mammalia, Xenarthra). - In: Fariña, R. A., Vizcaíno, S. F., Storch, G. (eds), Morphological studies in fossil and extant Xenarthra (Mammalia). Senckenbergiana biologica, 83(1): 5-17.

McDonald, H. G., Lundelius, E. L. Jr. (2009): The giant ground sloth Eremotherium laurillardi (Xenarthra, Megatheriidae) in Texas. - In: Albright, L. B., III (ed.), Papers on geology, vertebrate paleontology, and biostratigraphy in honor of Michael O. Woodburne. Bulletin, Museum of Northern Arizona, 65: 407-421.

McDonald, H. G., Muizon, C. de (2002): The cranial anatomy of Thalassocnus (Xenarthra, Mammalia), a derived nothrothere from the Neogene of the Pisco Formation (Peru).Journal of Vertebrate Paleontology, 22(2): 349-365. https://doi.org/10.1671/0272-4634(2002)022[0349:TCAOTX]2.0.CO;2

McKenna, M. C., Bell, S. K. (1997): Classification of Mammals Above the Species Level. - Columbia University Press, New York, Chichester, 631 pp.

Muizon, C. de, McDonald, H. G., Salas, R., Urbina, M. (2003): A new early species of the aquatic sloth Thalassocnus (Mammalia, Xenarthra) from the Late Miocene of Peru. - Journal of Vertebrate Paleontology, 23(4): 886-894. https://doi.org/10.1671/2361-13

Müller, G. B. (2007): Evo-devo: Extending the evolutionary synthesis. - Nature, Reviews Genetics, 8(12): 943-949. https://doi.org/10.1038/nrg2219

Negri, F. R., Ferigolo, J. (2004): Urumacotheriinae, nova subfamília de Mylodontinae (Mammalia, Tardigrada) do Mioceno superior-Plioceno, América do Sul [Urumacotheriinae, new subfamily of Mylodontinae (Mammalia, Tardigrada) from the upper Miocene-Pliocene, South America]. - Revista Brasileira de Paleontologia, 7(2): 281-288. (in Portuguese)

https://doi.org/10.4072/rbp.2004.2.23

van Nievelt, A. F., Smith, K. K. (2005): To replace or not to replace: the significance of reduced functional tooth replacement in marsupial and placental mammals. - Paleobiology, 31(2): 324-346.

https://doi.org/10.1666/0094-8373(2005)031[0324: TRONTR]2.0.CO;2

Paradis, E., Schliep, K. (2018): ape 5.0: an environment for modern phylogenetics and evolutionary analyses in R. Bioinformatics, 35(3): 526-528. https://doi.org/10.1093/ bioinformatics/bty 633

Pinheiro, J., Bates, D., DebRoy, S., Sarkar, D., Team, R. C. (2012). nlme: Linear and nonlinear mixed effects models. - R package version, 3(0).

Polly, P. D. (2007): Evolutionary biology: Development with a bite. - Nature, 449(7161): 413-415.

https://doi.org/10.1038/449413a
Presslee, S., Slater, G. J., Pujos, F., Forasiepi, A. M., Fischer, R., Molloy, K., Mackie, M., Olsen, J. V., Kramarz, A., Taglioretti, M., Scaglia, F., Lezcano, M., Lanata, J. L., Southon, J., Feranec, R., Bloch, J., Hajduk, A., Martin, F. M., Salas Gismondi, R., Reguero, M., de Muizon, C., Greenwood, A., Chait, B. T., Penkman, K., Collins, M., MacPhee, R. D. E. (2019): Palaeoproteomics resolves sloth relationships. - Nature Ecology and Evolution, 3: 1121-1130.

https://doi.org/10.1038/s41559-019-0909-z

Pujos, F., De Iuliis, G., Argot, C., Werdelin, L. (2007): A peculiar climbing Megalonychidae from the Pleistocene of Peru and its implication for sloth history. - Zoological Journal of the Linnean Society, 149(2): 179-235. https://doi.org/10.1111/j.1096-3642.2007.00240.x

Pujos, F., De Iuliis, G., Mamani Quispe, B., Adnet, S., Andrade Flores, R., Billet, G., Fernandes-Monescillo, M., Marivaux, L., Munch, P., Pramparo M. B., Antoine, P.-O. (2016): A new nothrotheriid xenarthran from the early Pliocene of Pomata-Ayte (Bolivia): new insights into the caniniform-molariform transition in sloths. Zoological Journal of the Linnean Society, 178(3): 679-712. https://doi.org/10.1111/zoj.12429

Pujos, F., De Iuliis, G., Quispe, B. M., Flores, R. A. (2014): Lakukullus anatisrostratus, gen. et sp. nov., a new massive nothrotheriid sloth (Xenarthra, Pilosa) from the middle Miocene of Bolivia. - Journal of Vertebrate Paleontology, 34(5): 1243-1248. https://doi.org/10.1080/02724634.2014.849716

Pujos, F., Gaudin, T. J., De Iuliis, G., Cartelle, C. (2012): Recent advances on variability, morpho-functional adaptations, dental terminology, and evolution of sloths. Journal of Mammalian Evolution, 19: 159-169. https://doi.org/10.1007/s10914-012-9189-y

Pujos, F., Salas-Gismondi, R., Baby, G., Baby, P., Goillot, C., Tejada, J., Antoine, P. O. (2013): Implication of the presence of Megathericulus (Xenarthra: Tardigrada: Megatheriidae) in the Laventan of Peruvian Amazonia. Journal of Systematic Palaeontology, 11(8): 973-991. https://doi.org/10.1080/14772019.2012.743488

Quiñones, S. I., Miño Boilini, Á. R., Zurita, A. E. (2017): Revisión del perezoso terrestre Nothropus (Mammalia, Xenarthra, Tardigrada) del Pleistoceno de Argentina y Bolivia [review of the ground sloth Nothropus (Mammalia, Xenarthra, Tardigrada) from the Pleistocene of Argentina and Bolivia]. - Revista Brasileira de Paleontologia, 20(1): 121-132. (in Spanish) https://doi.org/10.4072/rbp.2017.1.10

R Core Team (2019): R: A language and environment for statistical computing. R Foundation for Statistical Computing, Vienna, Austria. URL https://www.R-project.org/.

Renvoisé, E., Evans, A. R., Jebrane, A., Labruère, C., Laffont, R., Montuire, S. (2009): Evolution of mammal tooth patterns: new insights from a developmental prediction model. - Evolution, 63(5): 1327-1340. https://doi.org/10.1111/j.1558-5646.2009.00639.x

Rincón, A. D., Solórzano, A., McDonald, H. G., Flores, M. N. (2017): Baraguatherium takumara, gen. et sp. nov., the earliest Mylodontoid sloth (Early Miocene) from 
Northern South America. - Journal of Mammalian Evolution, 24(2): 179-191.

https://doi.org/10.1007/s10914-016-9328-y

Rinderknecht, A., Bostelmann, T. E., Perea, D., Lecuona, G. (2010): A new genus and species of Mylodontidae (Mammalia: Xenarthra) from the late Miocene of southern Uruguay, with comments on the systematics of the Mylodontinae. - Journal of Vertebrate Paleontology, 30(3): 899-910. https://doi.org/10.1080/02724631003757997

Rovereto, C. (1914): Los estratos araucanos y sus fósiles [The Araucanian strata and their fossils]. - Anales del Museo Nacional Buenos Aires, 25: 1-247. (in Spanish)

Rueden, C. T., Eliceiri, K. W. (2019). ImageJ for the Next Generation of Scientific Image Data. - Microscopy and Microanalysis, 25(S2): 142-143. https://doi.org/10.1017/S1431927619001442

Saint-André, P. A., Pujos, F., Cartelle, C., De Iuliis, G., Gaudin, T. J., McDonald, H. G., Mamani Quispe, B. (2010): Nouveaux paresseux terrestres (Mammalia, Xenarthra, Mylodontidae) du Néogène de l'Altiplano bolivien [New ground sloths (Mammalia, Xenarthra, Mylodontidae) from the Neogene of the Bolivian altiplano]. - Geodiversitas, 32(2): 255-306. (in French)

https://doi.org/10.5252/g2010n2a4

Savage, D. E. (1946): A mandible of Megalonyx from the Pleistocene of Oklahoma. - Journal of Mammalogy, 27(4): 388-390. https://doi.org/10.2307/1375347

Schroer, K., Wood, B. (2015): Modeling the dental development of fossil hominins through the inhibitory cascade. Journal of Anatomy, 226(2): 150-162. https://doi.org/10.1111/joa.12264

Scillato-Yané, G. J. (1977): Octomylodontinae: nueva subfamilia de Mylodontidae (Edentata, Tardigrada). Descripción del cráneo y mandíbula de Octomylodon robertoscagliai n. sp., procedentes de la Formación Arroyo Chasicó (Edad Chasiquense, Plioceno Temprano) del sur de la Provincia de Buenos Aires (Argentina). Algunas consideraciones filogenéticas y sistemáticas sobre los Mylodontoidea Octomylodontinae: nueva subfamilia de Mylodontidae (Edentata, Tardigrada) [Description of the skull and mandible of Octomylodon robertoscagliai n. sp., from the Arroyo Chasicó Formation (Chasicoan age, Early Pliocene) from the southern Buenos Aires province (Argentina). Some phylogenetic and systematic considerations on the Mylodontoidea]. - Publicaciones del Museo Municipal de Ciencias Naturales "Lorenzo Scaglia”, 2(5): 123-140. (in Spanish)

Scillato-Yané, G. J. (1981): Nuevo Mylodontinae (Edentata, Tardigrada) del "Mesopotamiense"(Mioceno Tardío-Plioceno) de la provincia de Entre Ríos [New Mylodontinae (Edentata, Tardigrada) from the "Mesopotamian"(Late Miocene-Pliocene) of Entre Ríos province]. - Ameghiniana, 18(1-2): 29-34. (in Spanish)

Scott, W. B. (1903): Part I. Edentata (Glyptodontia and Gravigrada (beginning)). - In: Scott, W. B. (ed.), Reports of the Princeton University Expeditions to Patagonia, 1896-1899. Princeton University, Schweizerbart'sche Verlagshandlung, Princeton, Stuttgart, 107-226 + pls XVII-XXXV.
Scott, W. B. (1904): Part I. Edentata (Gravigrada (completion)). - In: Scott, W. B. (ed.), Reports of the Princeton University Expeditions to Patagonia, 1896-1899. Princeton University, Schweizerbart'sche Verlagshandlung, Princeton, Stuttgart, pp. 227-364 + XXXVI-LXIII.

Shockey, B. J., Anaya, F. (2011): Grazing in a new late Oligocene mylodontid sloth and a mylodontid radiation as a component of the Eocene-Oligocene faunal turnover and the early spread of grasslands/savannas in South America. - Journal of Mammalian Evolution, 18(2): 101-115. https://doi.org/10.1007/s10914-010-9147-5

Smith, R. J. (2009): Use and misuse of the reduced major axis for line-fitting. - American Journal of Physical Anthropology, 140(3): 476-486. https://doi.org/10.1002/ajpa.21090

Storch, G. (1981): Eurotamandua joresi, ein Myrmecophagidae aus dem Eozän der "Grube Messel" bei Darmstadt (Mammalia, Xenarthra) [Eurotamandua joresi, Myrmecophagidae from the Eocene of "Grube Messel" near Darmstadt (Mammalia, Xenarthra)]. - Senckenbergiana lethaea, 61(3-6): 247-289. (in German)

Taglioretti, M., Miño-Boilini, Á. R., Scaglia, F., Dondas, A. (2014): Presencia de Proscelidodon patrius (Xenarthra, Scelidotheriinae) en la Formación Chapadmalal (Plioceno superior), Mar del Plata, Buenos Aires, Argentina: implicancias bioestratigráficas [Presence of Proscelidodon patrius (Xenarthra, Scelidotheriinae) in the Chapadmalal Formation (Upper Pliocene), Mar del Plata, Buenos Aires, Argentina: stratigraphical implications]. Ameghiniana, 51(5): 420-427. (in Spanish) https://doi.org/10.5710/AMGH.04.08.2014.2715

Townsend, G. C., Brown, T. (1981): Morphogenetic fields within the dentition. - Australian Orthodontic Journal, 7(1): 3-12.

Varela, L., Fariña, R. A. (2016): Co-occurrence of mylodontid sloths and insights on their potential distributions during the late Pleistocene.- Quaternary Research, 85(1): 66-74. https://doi.org/10.1016/j.yqres.2015.11.009

Varela, L., Tambusso, P. S., McDonald, H. G., Fariña, R. A. (2018): Phylogeny, macroevolutionary trends and historical biogeography of sloths: insights from a Bayesian morphological clock analysis. - Systematic Biology, 25(11): 204-218. https://doi.org/10.1093/sysbio/syy058

Villarroel, C. (2000): Un nuevo Mylodontinae (Xenarthra, Tardigrada) en la fauna de La Venta, Mioceno de Colombia: el estado actual de la familia Orophodontidae [A new Mylodontinae (Xenarthra, Tardigrada) in the fauna of La Venta, Miocene of Colombia: the current status of the family Orophodontidae]. - Revista de la Academia colombiana de ciencias exactas, físicas y naturales, 24(90): 117-127. (in Spanish)

Vizcaíno, S. F. (2009): The teeth of the "toothless": novelties and key innovations in the evolution of xenarthrans (Mammalia, Xenarthra). - Paleobiology, 35(3): 343-366. https://doi.org/10.1666/0094-8373-35.3.343

Vizcaíno, S. F., Bargo, M. S., Cassini, G. H. (2006): Dental occlusal surface area in relation to body mass, food habits and other biological features in fossil xenarthrans. Ameghiniana, 43(1), 11-26. 
Webb, S. D. (1989): Osteology and relationships of Thinobadistes segnis, the first mylodont sloth in North America. - In: Redford, K. H., Eisenberg, J. F. (eds), Advances in Neotropical Mammalogy. Sandhill Crane Press, Gainesville, pp. 469-532.
Wilson, L. A., Madden, R. H., Kay, R. F., Sánchez-Villagra, M. R. (2012): Testing a developmental model in the fossil record: molar proportions in South American ungulates. - Paleobiology, 38(2): 308-321. https://doi.org/10.1666/11001.1 